\title{
Civic Science in Urban Forestry: An Introduction
}

\author{
Lara A. Roman, Lindsay K. Campbell, and Rebecca C. Jordan
}

\begin{abstract}
Civic science in urban forestry is a means of engaging the public in the study, management, and care of urban trees, and includes varied approaches with different disciplinary foundations. For instance, citizen science has been gaining prominence in urban forestry, with municipalities and nonprofits engaging volunteers in data collection for inventories and monitoring. Residents can also get involved in other stages of urban forest research and management, including framing goals and questions, conducting analyses, interpreting data, and applying results. Diverse forms of public engagement have brought expanded stakeholders into the fold of knowledge production and stewardship of urban greenspaces, including co-management and civic ecology practices. As municipalities, states, nonprofits, and scientists undertake these various forms of civic science, there is a need for basic research about the nature of civic engagement in urban forestry, empirical evidence about best practices for different approaches, and the impacts of volunteering on the participants themselves. This special issue of Arboriculture \& Urban Forestry aims to advance the scholarship of civic science in urban forestry by addressing these topics, among others, with contributed articles. In this introduction to the special issue, we briefly review terms related to civic science to connect these interrelated bodies of inquiry to urban forestry, and present the research studies and practitioner notes included in this special issue. We then conclude with a discussion of future research needs for civic science in urban forestry, including technological tools to enable data democratization, engaging marginalized and under-represented urban communities, and supporting transdisciplinary exchanges between research and practice.

Key Words. Citizen Science; Civic Ecology; Co-Management; Knowledge Co-Production; Participatory Research; Urban Ecology; Urban Forestry.
\end{abstract}

This special issue grew from a symposium entitled "Citizen Science \& Urban Forestry: Research \& Practice," held in May 2016 and hosted by the United States Department of Agriculture (USDA) Forest Service Philadelphia Field Station and the Pennsylvania Horticultural Society. Presentation topics spanned participant learning, civic ecology practices, technologies for citizen science, data quality considerations, and the practical application of citizen science to urban forest management. Presenters and attendees included research scientists, public land managers, nonprofit leaders, and civic stewards-reflecting the broad interest in applied research and adaptive management approaches to advance the practice of urban forestry. The development of the symposium was inspired by the sense that while citizen science has recently been applied to a wide range of urban forest management needs-including street tree inventories (Kocher 2012; Campbell 2015; DiSalvo et al. 2017), tree survival monitoring (Roman et al. 2013), and detection of invasive plants and diseases (Haw- thorne et al. 2015; Meetenmeyer et al. 2015) -it has not yet received much attention in the scholarly literature, with the exception of a few studies of volunteer data quality (Bloniarz and Ryan 1996; Cozad 2005; Roman et al. 2017). There is, however, an extensive body of literature on citizen science in other ecological systems, such as public parklands and coastal aquatic communities, and taxonomic groups such as birds, butterflies, frogs, and plants (Bonney et al. 2009; Dickinson et al. 2010; Dickinson et al. 2012; Tulloch et al. 2013). Meanwhile, urban forestry researchers have been exploring other aspects of civic engagement, including how diverse stakeholders are networked in the stewardship of urban greenspaces and management of ecosystem services (Connolly et al. 2014), participatory urban forest planning (Van Herzele et al. 2005; Janse and Konijnendijk 2007), stewardship outcomes monitoring (Silva and Krasny 2014), and knowledge co-production (Campbell et al. 2016). We initiated this special issue to advance a broader awareness and understanding of 
civic engagement in the study, management, and care of trees in cities, towns, and communitieswhich we refer to as civic science in urban forestry.

\section{REVIEW OF KEY TERMS AND CONCEPTS}

Public engagement in the science and management of natural resources has received tremendous attention in the ecology, conservation, and sustainability literatures. We offer definitions of several relevant terms in Table 1, while recognizing that many different definitions of these terms have been articulated with meanings that have evolved over time. These terms also overlap with various other concepts, such as community-based monitoring, participatory action research, and public participation in scientific research (Kindon et al. 2007; Minkler and Wallerstein 2008; Conrad and Hilchy 2011; Shirk et al. 2012). Many of these approaches can be characterized as civic science for sustainability, with common threads of enhancing public participation and representation of marginalized voices, as well as democratization of the scientific process (Bäckstrand 2003).

Broadly speaking, these civic science approaches attempt to move past conventional ways of conducting resource management and scientific research, which typically have top-down hierarchical structures that do not involve communities (Bäckstrand 2003; Berkes 2009; McKinley et al. 2013). Concepts such as co-management and community-based natural resource management originated in rural landscapes-recognizing the value of partnerships between local communities and government agencies to do science and manage landscapes - and have evolved to be applied in the urban realm as well (Koontz et al. 2004; Fortmann 2008; Berkes 2009; Burch et al. 2017). In addition to co-management, scholars have demonstrated the diversity of governance arrangements that support urban forests (Lawrence et al. 2013). Participatory research approaches from public health and human geography, such as community-based participatory research and participatory action research, emphasize that researchers and community members are engaged in a process of co-learning and cooperation with genuine partnership and power-sharing that leads to both knowledge co-production and real-world action (Israel et al. 1998; O'Fallon and Dearry 2002; Pain 2003; Kindon et al. 2007; Minkler and Wallerstein 2008). The participatory research approach emphasizes community engagement throughout all stages of the research process, from defining the problem through collecting data, interpreting results, and translating the findings into action (Israel et al. 1998).

Recent literature on community engagement in urban forestry has focused on networks of urban environmental stewardship, participatory planning, and civic ecology. Many cities across the United States and around the world have set goals to expand and enhance their urban tree canopy and have invested in green infrastructure as a part of sustainability and resilience plans (Schäffler and Swilling 2013; Young and McPherson 2013; Kimball et al. 2014; Young et al. 2014; Norton et al. 2015; Hauer and Peterson 2016; Campbell 2017). In some cases, particularly in European examples, these sustainability and greening efforts are undertaken as participatory planning endeavors that engage the public in shaping the planning and management of urban greenspaces (Van Herzele et al. 2005; Janse and Konijnendijk 2007). Governance of urban ecosystems occurs across sectors and scales, via collaborative ties and polycentric, networked flows of information and resources (Connolly et al. 2013). As such, in addition to the actions of municipal agencies and private landowners in managing the urban forest, communitybased groups and non-governmental organizations have a key role to play in civic stewardship of these resources (Svendsen et al. 2016). These stewards engage in conservation, management, education, advocacy, transformation, and monitoring of the urban environment (Svendsen and Campbell 2008; Fisher et al. 2012). Civic stewards' involvement in environmental monitoring is connected to the previously articulated traditions of public participation in scientific research (Silva and Krasny 2014) and citizen science (Bonney et al. 2009), as well as action research for the environmental health of urban communities, such as "bucket brigades" that detect and report on local environmental quality (O’Rourke \& Macey 2003; Corburn 2005). Scholars writing about co-management and civic ecology have emphasized the ways that community engagement in natural resource stewardship can foster social learning (Berkes 2009; Tidball et al. 2010). 
Table 1. Terms related to public participation in the science and management of natural resources.

\begin{tabular}{|c|c|}
\hline Term & Definition \\
\hline Citizen science & $\begin{array}{l}\text { "[P]artnerships between scientists and non-scientists in which authentic data are collected, } \\
\text { shared, and analyzed" (Jordan et al. 2012), while in the ecological sciences, a citizen scientist is } \\
\text { sometimes considered "a volunteer who collects and/or processes data as part of a scientific } \\
\text { enquiry" (Silvertown 2009). }\end{array}$ \\
\hline Civic ecology & $\begin{array}{l}\text { "[A] field of interdisciplinary study concerned with individual, community, and environmental } \\
\text { outcomes of community-based environmental stewardship practices, and the interactions of such } \\
\text { practices with people and other organisms, communities, governance institutions, and the ecosys- } \\
\text { tems in which those practices take place" and "civic ecology practices are self-organizing steward- } \\
\text { ship initiatives, often taking place in cities" (Krasny and Tidball 2012). }\end{array}$ \\
\hline Civic science & $\begin{array}{l}\text { "Civic science alludes to a changing relationship between science, expert knowledge and citizens } \\
\text { in democratic societies. In this perspective, citizens and the public have a state in the science- } \\
\text { politics interface, which can no longer be viewed as an exclusive domain for scientific experts and } \\
\text { policy-makers only," with dimensions of civic science emphasizing public participation, enhancing } \\
\text { representation of marginalized voices, and democratization of the scientific process (Bäckstrand } \\
2003 \text { ). }\end{array}$ \\
\hline $\begin{array}{l}\text { Community-based natural } \\
\text { resource management } \\
(\text { CBNRM) }\end{array}$ & $\begin{array}{l}\text { "[A] mechanism to address both environmental and socio-economic goals and to balance the } \\
\text { exploitation and conservation of valued ecosystem components", which "requires some degree } \\
\text { of devolution of decision-making power and authority over natural resources to communities and } \\
\text { community-based organizations" (Armitage 2005, and citations therein). }\end{array}$ \\
\hline $\begin{array}{l}\text { Community-based } \\
\text { participatory research (CBPR) }\end{array}$ & $\begin{array}{l}\text { "[A] collaborative approach to research that equitably involves all partners in the research process } \\
\text { and recognizes the strengths that each brings. CBPR begins with a research topic of importance } \\
\text { to the community with the aim of combining knowledge and action for social change to improve } \\
\text { community health and eliminate health disparities" (Kellogg 2001, qtd. in Minkler and Wallerstein } \\
\text { 2008). }\end{array}$ \\
\hline Co-management & $\begin{array}{l}\text { "[T] he sharing of power and responsibility between the government and local resource users" } \\
\text { (Berkes 2009). }\end{array}$ \\
\hline Crowdsourcing & $\begin{array}{l}\text { "[T] he practice of obtaining information or input into a task or project by enlisting the services of } \\
\text { a large number of people, either paid or unpaid" (OED 2017), either via the internet, or in ecology } \\
\text { and conservation, crowdsourcing can also involve field data (Dickinson et al. 2010). }\end{array}$ \\
\hline Knowledge co-production & $\begin{array}{l}\text { "[T] he collaborative process of bringing a plurality of knowledge sources and types together to } \\
\text { address a defined problem and build an integrated or systems-oriented understanding of that } \\
\text { problem" (Armitage et al. 2011), typically related to co-management of natural resources. }\end{array}$ \\
\hline
\end{tabular}

\section{PAPERS IN THIS SPECIAL ISSUE}

The papers in this special issue include both Original Research and Short Communication articles. We are using Short Communication articles as practitioner notes for urban forestry professionals and researchers to share evidence-based evaluations of their program, addressing topics such as best practices for citizen science, data quality, programmatic motivations for engaging volunteers, cost-effectiveness, and cross-program comparisons (such articles are designated with $\dagger$ ). We briefly summarize below the six articles featured in this special issue. These articles span topics of civic science program operations and process, including projects initiated by municipalities and researchers as well as collegial projects initiated by amateurs; resident and volunteer attitudes, motivations, and participation; and volunteer data quality and training. Additional articles are anticipated in a forthcoming, second special issue. Crown et al. (this issue $\dagger$ ) provides a municipal urban forest management perspective on citizenscience inventories. The project described is TreesCount! 2015, the third decadal volunteer street tree inventory in New York City, New York, U.S., led by the city's Department of Parks and Recreation. This article details how the data were collected and compares outcomes to the previous inventories. The authors discuss technological tools that can enhance both participation and accuracy, and conclude with numerous recommendations for those seeking to do similar work. Providing further insight into this city's street tree inventory, Johnson et al. (this issue) investigated volunteer motivations for participation, analyzing these motivations by participant demographics. Similar to other 
citizen science programs (see review in Jordan et al. 2015), these authors report personal interest, wanting to contribute something beneficial for society, and learning opportunities as top motivations. Many of the volunteers expressed an interest in exploring the city through the process of conducting the street tree inventory, which required travel within the city and hands-on engagement with a variety of different neighborhoods. The authors also include recommendations to increase participation across diverse communities.

Given that data quality is a concern for citizen science projects involving novice participants (Roman et al. 2017), Bancks et al. (this issue) analyzed agreement between tree data produced by volunteers and university research staff. The projects assessed were surveys and inventories conducted in preparation for emerald ash borer in Minnesota, U.S., a central management concern for many communities in the Midwestern and eastern regions of the United States and Canada (Fahrner et al. 2017; Hauer and Peterson 2017). Volunteers and researchers had the highest agreement for genus identification (>90\%). The study found differences in data quality according to training method, suggesting that additional focus on instructing volunteers in the field, as well as technical assistance, produced better outcomes. The authors recommend that decisions to use citizen science data should incorporate considerations for appropriate training methods and data specificity requirements for the project.

Recognizing the value of volunteers for various in municipal forestry programs, Hauer et al. (this issue) conducted a national survey of tree activities in over 660 municipalities across the United States. Two-thirds of the responding municipalities involve volunteers in urban forestry activities, with rates increasing for large cities. Volunteer activities included tree planting, maintenance, awareness, and fundraising. The authors estimated the number of people and hours that volunteers contribute to urban forestry across the nation, and analyzed attributes of municipal forestry programs that predicted the presence of volunteer participation. This study provides a baseline for volunteerism in municipal forestry in the United States, enabling future comparisons, as volunteer levels and roles may change.
Focusing on trees in residential properties, which constitute a substantial portion of many urban forests (Nguyen et al. 2017), Almas and Conway (this issue) studied attitudes toward native species among residents of four southern Ontario, Canada, communities. Residential attitudes and knowledge about native species are relevant to species-selection choices. The authors report generally favorable attitudes toward native tree species. When exploring purchasing behavior, however, native trees are less likely to be purchased. These authors conclude with not only a call for educational outreach regarding native trees but also greater availability of natives in places where the public purchases trees.

Finally, Silvera Seamans (this issue $\dagger$ ) describes the research processes and outcomes of four collegial citizen science projects about urban spontaneous vegetation in the New York City region. Unlike traditional scientific research or even other typical forms of citizen science, these projects were all initiated by artists and designers working outside of formal scientific institutions. These projects work to document, make visible, and reshape public perceptions of spontaneous vegetation-often considered as "weeds" or problem plants-to consider the ecosystem functions and intrinsic values of this novel urban flora. This paper shows that collegial science conducted by "amateurs" is not a practice relegated to history but remains a lively arena of conversation and public engagement in the 21 st century.

\section{FUTURE RESEARCH NEEDS FOR CIVIC SCIENCE IN URBAN FORESTRY}

This special issue begins to illuminate some of the novel and emerging research on civic science in urban forestry, but much more remains to be learned. Based on these articles and with insight from the May 2016 symposium, we suggest several new avenues to advance scholarship. First, with the public involved in data collection and analysis in many forms of civic science, research should explore the role of technology and cyber infrastructure to enable democratization of data access. This involves open-data concepts (Reichman et al. 2011; Janssen et al. 2012), but beyond simply sharing the raw data, data vi- 
sualizations and summaries could help practitioners and communities actually apply and use the data. User accessibility therefore needs to be at the forefront of any efforts in data democratization.

Second, civic science approaches emphasize the importance of engaging with diverse communities and empowering marginalized voices, yet public engagement in large-scale volunteer urban tree planting and citizen science tree inventories has often been skewed toward limited subsets of the urban population (Fisher et al. 2015; Johnson et al. this issue). Further research is needed to identify barriers to participation among marginalized communities (Pandya 2012). Researchers and managers can also seek opportunities to create novel approaches that incorporate perspectives from diverse stakeholders, such as artists, youth, and indigenous populations into natural resources stewardship by building upon and strengthening relations of care and reciprocity (Kealiikanakaoleohaililani et al. in press; Silvera Seamens this issue).

Third, new research should examine the various processes and institutional structures that link research to practice. Such research should identify mechanisms and feedback loops for translating studies into action, turning management needs into research priorities, and jointly posing truly transdisciplinary questions that integrate research and praxis at the outset. This could include assessments of how to effectively integrate researcherpractitioner dialogue and co-learning throughout the research process. This avenue of study would build on previous work about hybrid organizations (Fisher and Svendsen 2014), knowledgeaction networks (Muñoz-Erickson et al. 2014), varied structures of urban forest governance (Lawrence et al. 2013), and transdisciplinary knowledge production in social-ecological systems (Lang et al. 2012; Johnson et al. in press).

The civic-science studies and practitioner notes presented in this special issue demonstrate the critical need for further study of such topics to advance the management and science of urban forestry, recognizing the multifaceted and valuable roles that the public plays in stewarding and studying urban trees and green spaces.
Acknowledgments. We thank all the presenters and participants at the May 2016 symposium, "Citizen Science \& Urban Forestry: Research \& Practice." We are especially grateful to the scholars and professionals who joined us after the symposium for a workshop to discuss new directions for citizen science in urban forestry: G. Abrams, D. Boyer, D. Dentice, A. DiSalvo, J. Henning, J. Greenfeld, S. Lerman, S. Low, M. Maslin, J. Sanders, P. Silva, and A, Sorensen. Our discussion of future research needs in this paper builds on that workshop. We also appreciate the sponsors of the symposium: the USDA Forest Service Philadelphia Field Station, the Pennsylvania Horticultural Society, and Azavea. Finally, we thank M. Kondo for comments on a previous draft of this article, and J. Grabosky for encouraging us to organize this special issue.

Supplemental Content. This issue of Arboriculture \& Urban Forestry contains a number of supplemental materials the editorial team was not able to include in the print version of the journal. This supplemental content is available for browsing on the website of the publisher, International Society of Arboriculture (www.isa-arbor.com). For additional guidance, or to obtain specific supplemental content as an electronic file (.pdf), please contact ISA editorial (editor@isa-arbor.com).

\section{LITERATURE CITED}

Armitage, D. 2005. Adaptive capacity and community-based natural resource management. Environmental Management 35:703-715.

Armitage, D., F. Berkes, A. Dale, E. Kocho-Schellenberg, and E. Patton. 2011. Co-management and the co-production of knowledge: Learning to adapt in Canada's Arctic. Global Environmental Change 21:995-1004.

Bäckstrand, K. 2003. Civic science for sustainability: Reframing the role of experts, policy-makers, and citizens in environmental governance. Global Environmental Politics 3:24-41.

Berkes, F. 2009. Evolution of co-management: Role of knowledge generation, bridging organizations and social learning. Journal of Environmental Management 90:1692-1702.

Bloniarz, D.V., and H.D.P. Ryan. 1996. The use of volunteer initiatives in conducting urban forest resource inventories. Journal of Arboriculture 22:75-82.

Bonney, R., C.B. Cooper, J. Dickinson, S. Kelling, T. Phillips, K.V. Rosenberg, and J. Shirk. 2009. Citizen science: A developing tool for expanding scientific knowledge and scientific literacy. BioScience 59:977-984.

Burch, W., G.E. Machlis, and J.E. Force. 2017. The Structure and Dynamics of Human Ecosystems: Toward a Model for Understanding and Action. Yale University Press, New Haven, Connecticut, U.S. 312 pp.

Campbell, J. 2015. NYC's decennial street tree census will enter the digital age this year. The Village Voice, 30 April 2015. Accessed 10 November 2017. <www.villagevoice.com/2015/04/30/nycsdecennial-street-tree-census-will-enter-the-digital-age-thisyear>

Campbell, L.K. 2017. City of forests, city of farms: Sustainability planning for New York City's nature. Cornell University Press, Ithaca, New York, U.S. 290 pp. 
Campbell, L.K., E.S. Svendsen, and L.A. Roman. 2016. Knowledge co-production at the research-practice interface: Embedded case studies from urban forestry. Environmental Management $57: 1262-1280$.

Connolly, J.J., E.S. Svendsen, D.R. Fisher, and L.K. Campbell. 2013. Organizing urban ecosystem services through environmental stewardship governance in New York City. Landscape and Urban Planning 109:76-84.

Connolly, J.J., E.S. Svendsen, D.R. Fisher, and L.K. Campbell. 2014. Networked governance and the management of ecosystem services: The case of urban environmental stewardship in New York City. Ecosystem Services 10:187-194.

Conrad, C.C., and K.G. Hilchy. 2011. A review of citizen science and community-based environmental monitoring: Issues and opportunities. Environmental Monitoring \& Assessment 176:273-291.

Corburn, J. 2005. Street science: Community knowledge and environmental health justice. MIT Press, Cambridge, Massachusetts, U.S. 281 pp.

Cozad, S. 2005. STRATUM case study evaluation in Minneapolis, Minnesota. Master's Thesis. University of California, Davis. 81 pp.

Dickinson, J.L., B. Zuckerberg, and D.N. Bonter. 2010. Citizen science as an ecological research tool: Challenges and benefits. Annual Review of Ecology and Systematics 41:149-172.

Dickinson, J.L., J. Shirk, D. Bonter, R. Bonney, R.L. Crain, J. Martin, T. Phillips, and K. Purcell. 2012. The current state of citizen science as a tool for ecological research and public engagement. Frontiers in Ecology and the Environment 10:291-297.

DiSalvo, A., J. Fukuda, and J. Ramsay. 2017. Street tree inventory report: City of Portland. Portland Parks \& Recreation. 43 pp. Accessed 10 November 2017. <www.portlandoregon.gov/parks/ article/638773>

Fahrner, S.J., M. Abrahamson, R.C. Venette, and B.H. Aukema. 2017. Strategic removal of host trees in isolated, satellite infestations of emerald ash borer can reduce population growth. Urban Forestry \& Urban Greening 24:184-194.

Fisher, D.L., J.J. Connolly, E.S. Svendsen, and L.K. Campbell. 2012. Digging together: Why people volunteer to help plant one million trees in New York City. Environmental stewardship project at the center for society and environment of the University of Maryland. White Paper \#2. 36 pp. Accessed 10 November 2017. $<$ http://nrs.fs.fed.us/nyc/local-resources/downloads/Digging Together_White_Paper.pdf>

Fisher, D.R., E.S. Svendsen, and J. Connolly. 2015. Urban environmental stewardship and civic engagement: How planting trees strengthens the roots of democracy. Routledge Press, New York, New York, U.S. 164 pp.

Fisher, D.R., and E.S. Svendsen. 2014. Hybrid arrangements within the environmental state. pp. 179-189. In: S. Lockie, D. Sonnenfeld, and D. Fisher (Eds.). Sociological methods. Routledge international handbook of social and environmental change. Routledge Press, New York, New York, U.S.

Fortmann, L. (Ed.). 2008. Participatory research in conservation and rural livelihoods: Doing science together. Wiley-Blackwell, New York, New York, U.S. 316 pp.

Hauer, R.J., and W.D. Peterson. 2016. Municipal tree care and management in the United States: A 2014 urban and community forestry census of tree activities. Special Publication 16-1, College of Natural Resources, University of Wisconsin-Stevens Point. $71 \mathrm{pp}$.
Hauer, R.J., and W.D. Peterson. 2017. Effects of emerald ash borer on municipal forestry budgets. Landscape and Urban Planning 157:98-105.

Hawthorne, T.L., V. Elmore, A. Strong, P. Bennett-Martin, J. Finnie, J. Parkman, and T. Harris, et al. 2015. Mapping non-native invasive species and accessibility in an urban forest: A case study of participatory mapping and citizen science in Atlanta, Georgia. Applied Geography 56:187-198.

Israel, B.A., A.J. Schulz, E.A. Parker, and A.B. Becker. 1998. Review of community-based participatory research: Assessing partnership approaches to improve public health. Annual Review of Public Health 19:173-202.

Janse, G., and C.C. Konijnendijk. 2007. Communication between science, policy, and citizens in public participation in urban forestry-Experiences from the Neighbourwoods project. Urban Forestry \& Urban Greening 6:23-40.

Janssen, M., Y. Charalabidis, and A. Zuiderwijk. 2012. Benefits, adoption barriers and myths of open data and open government. Journal of Information Systems Management 29:258-268.

Johnson, M., D.S. Novem Auyeung, N.S. Sonti, C.C. Pregitzer, H.L. McMillen, R. Hallett, and L.K. Campbell, et al. In press. Socialecological research in urban natural areas: An emergent process for integration. Urban Ecosystems.

Jordan, R.C., H.L. Ballard, and T.B. Phillips. 2012. Key issues and new approaches for evaluating citizen-science learning outcomes. Frontiers in Ecology and the Environment 10:307-309.

Jordan, R., A. Crall, S. Gray, T. Phillips, and D. Mellor. 2015. Citizen science as a distinct field of inquiry. BioScience 65:208-211.

Kealiikanakaoleohaililani, K., H. McMillen, C. Giardina, and K. Francisco. Cultivating sacred kinship to strengthen resilience. In press. Green readiness, response, and recovery: A collaborative synthesis, General Technical Report. USDA Forest Service: Newtown Square, Pennsylvania, U.S.

W.K. Kellogg Foundation Community Health Scholars Program (Kellogg). 2001. Stories of impact (brochure). Ann Arbor: University of Michigan, School of Public Health, Community Health Scholars Program, National Program Office. qtd. in Minkler and Wallerstein (2008).

Kimball, L.L., P.E. Wiseman, S.D. Day, and J.F. Munsell. 2014. Use of urban tree canopy assessments by localities in the Chesapeake Bay Watershed. Cities and the Environment 7(2):article 9.

Kindon, S., R. Pain, and M. Kesby (Eds.). 2007. Participatory action research approaches and methods: Connecting people, participation and place. Routledge Press, New York, New York, U.S. $260 \mathrm{pp}$.

Kocher, W. 2012. New software for tree inventory and urban forest outreach. Arborist News 21:50-51.

Koontz, T., T. Steelman, J. Carmin, K. Korfmacher, C. Moseley, and C. Thomas. 2004. Collaborative environmental management: What roles for government? Washington, D.C.: Resources for the Future.

Krasny, M.E., and K.G. Tidball. 2012. Civic ecology: A pathway for Earth stewardship in cities. Frontiers in Ecology and the Environment 10:267-273.

Lang, D.J., A. Wiek, M. Bergmann, M. Stauffacher, P. Martens, P. Moll, M. Swilling, and C.J. Thomas. 2012. Transdisciplinary research in sustainability science: Practice, principles, and challenges. Sustainability Science 7:25-43.

Lawrence, A., R. De Vreese, M. Johnston, C.C. Konijnendijk van den Bosch, and G. Sanesi. 2013. Urban forest governance: 
Towards a framework for comparing approaches. Urban Forestry \& Urban Greening 12:464-473.

McKinley, D.C., R.D. Briggs, and A.M. Bartuska. 2013. When peerreviewed publications are not enough! Delivering science for natural resource management. Forest Policy and Economics 21:1-11.

Meetenmeyer, R.K., M.A. Dorning, J.B. Vogler, D. Schmidt, and M. Garbelotto. 2015. Citizen science helps predict risk of emerging infectious disease. Frontiers in Ecology and the Environment 13:189-194.

Minkler, M., and N. Wallerstein. 2008. Community-based participatory research for health: From process to outcomes, second edition. Jossey-Bass, Hoboken, New Jersey, U.S. 544 pp.

Muñoz-Erickson, T.A., A.E. Lugo, E. Meléndez-Ackerman, L.E. Santiago-Acevedo, J. Seguinot-Barbosa, P. Méndez-Lázaro, M. Hall, and B. Quintero, et al. 2014. Knowledge to serve the city: Insights from an emerging knowledge-action network to address vulnerability and sustainability in San Juan, Puerto Rico. Cities and the Environment 7(1):article 5.

Nguyen, V.D., L.A. Roman, D.H. Locke, S.K. Mincey, J.R. Sanders, E. Smith Fichman, M. Duran-Mitchell, and S. Lumban Tobing. 2017. Branching out to residential lands: Missions and strategies of five tree distribution programs in the U.S. Urban Forestry \& Urban Greening 22:24-35.

Norton, B.A., A.M. Coutts, S.J. Livesley, R.J. Harris, A.M. Hunter, and N.S.G. Williams. 2015. Planning for cooler cities: A framework to prioritize green infrastructure to mitigate high temperatures in urban landscapes. Landscape and Urban Planning 134:127-138.

O'Fallon, L.R., and A. Dearry. 2002. Community-based participatory research as a tool to advance environmental health sciences. Environmental Health Perspectives 110:155-159.

O’Rourke, D., and G.P. Macey. 2003. Community environmental policing: Assessing new strategies of public participation in environmental regulation. Journal of Policy and Analysis and Management 22:383-414.

Oxford English Dictionary. 2017. Crowdsourcing. Oxford: Oxford University Press. <www.oed.com>

Pain, R. 2003. Social geography: On action-oriented research. Progress in Human Geography 27:649-657.

Pandya, R.E. 2012. A framework for engaging diverse communities in citizen science in the U.S. Frontiers in Ecology and the Environment 10:314-317.

Reichman, O.J., M.B. Jones, and M.P. Schildhauer. 2011. Challenges and opportunities of open data in ecology. Science 331:703-705.

Roman, L.A., E.G. McPherson, B.C. Scharenbroch, and J. Bartens. 2013. Identifying common practices and challenges for local urban tree monitoring programs in the United States. Arboriculture \& Urban Forestry 39:292-299.

Roman, L.A., B.C. Scharenbroch, J.P.A. Östberg, L.S. Mueller, J.G. Henning, A.W. Koeser, and J.R. Sanders, et al. 2017. Data quality in citizen science urban tree inventories. Urban Forestry \& Urban Greening 22:124-135.

Schäffler, A., and M. Swilling. 2013. Valuing green infrastructure in an urban environment under pressure-The Johannesburg case. Ecological Economics 86:246-257.

Shirk, J.L., H.L. Ballard, C.C. Wilderman, T. Phillips, A. Wiggins, R. Jordan, and E. McCallie, et al. 2012. Public participation in scientific research: A framework for deliberate design. Ecology \& Society 17(2):29.
Silva, P., and M.E. Krasny. 2014. Parsing participation: Models of engagement for outcomes monitoring in urban stewardship. Local Environment: The International Journal of Justice and Sustainability. <doi: 10.1080/13549839.2014.929094>

Silvertown, J. 2009. A new dawn for citizen science. Trends in Ecology and Evolution 24:467-471.

Svendsen, E.S., and L.K. Campbell. 2008. Urban ecological stewardship: Understanding the structure, function and network of community-based urban land management. Cities and the Environment 1(1):article 5.

Svendsen, E.S., L.K. Campbell, D.R. Fisher, J.J.T. Connolly, M.L. Johnson, N.F. Sonti, and D.H. Locke, et al. 2016. Stewardship mapping and assessment project: A framework for understanding community-based environmental stewardship. GTR NRS156. Newtown Sq., Pennsylvania, U.S. U.S. Department of Agriculture, Forest Service. 134 pp.

Tidball, K.G., M.E. Krasny, E. Svendsen, L. Campbell, and K. Helphand. 2010. Stewardship, learning, and memory in disaster resilience. Environmental Education Research 16:591-609.

Tulloch, A.I.T., H.P. Possingham, I.N. Joseph, J. Szabo, and T.G. Martin. 2013. Realizing the full potential of citizen science monitoring programs. Biological Conservation 165:128-138.

Van Herzele, A., K. Collins, and L. Tyrväinen. 2005. Involving people in urban forestry-A discussion of participatory practices throughout Europe. pp. 207-227. In: C.C. Konijnendijk, K. Nilsson, T. Randrup, and J. Schipperijn (Eds.). Urban Forests and Trees. Springer, Berlin, Germany. 520 pp.

Young, R.F., and E.G. McPherson. 2013. Governing metropolitan green infrastructure in the United States. Landscape and Urban Planning 109:67-75.

Young, R., J. Zanders, K. Lieberknecht, and E. Fassman-Beck. 2014. A comprehensive typology for mainstreaming urban green infrastructure. Journal of Hydrology 519:2571-2583.

Lara A. Roman (corresponding author)

USDA Forest Service Northern Research Station, Philadelphia

Field Station

100 N 20th St. Suite 205

Philadelphia, Pennsylvania 19103, U.S.

lroman@fs.fed.us

Lindsay K. Campbell

USDA Forest Service Northern Research Station

290 Broadway, 26th Floor

New York, New York 10007, U.S.

Rebecca C. Jordan

Rutgers The State University of New Jersey

New Brunswick, New Jersey, U.S. 
Résumé. La science citoyenne en foresterie urbaine est un moyen d'impliquer le public dans l'étude, la gestion et l'entretien des arbres urbains, elle implique différentes approches avec des bases disciplinaires variées. Par exemple, la science citoyenne a pris de l'importance en foresterie urbaine avec la pratique des municipalités et des organismes sans but lucratif d'engager des bénévoles pour faire la collecte de données d'inventaires et de la surveillance. Les citoyens peuvent également participer à d'autres étapes de recherche et de gestion des forêts urbaines, y compris l'établissement des buts et des interrogations, la réalisation d'analyses, l'interprétation de données et l'application des résultats. Diverses formes d'engagement public ont amené des intervenants variés dans le giron de la production du savoir et de l'intendance des espaces verts urbains, y compris les pratiques de cogestion et d'écologie civique. À mesure que les municipalités, les états, les organismes sans but lucratif et les scientifiques expérimentent ces diverses formes de science citoyenne, il existe un besoin en recherche fondamentale sur la nature de l'engagement civique en foresterie urbaine, des données empiriques sur les meilleures pratiques selon les différentes approches et les impacts du bénévolat sur les participants eux-mêmes. Cette édition spéciale de l'Arboriculture \& Urban Forestry vise à faire progresser le savoir de la science citoyenne en foresterie urbaine en abordant ces sujets, parmi d'autres, avec des articles pertinents. Dans l'introduction de cette édition spéciale, nous passons rapidement en revue les termes associés à la science citoyenne pour rattacher ces instances d'enquête interdépendants à la foresterie urbaine et présentons les recherches et les notes de praticiens participant à cette édition spéciale. Nous concluons alors par une discussion sur les besoins futurs en recherche concernant la science citoyenne en foresterie urbaine, incluant les outils technologiques favorisant la démocratisation des données, l'implication des communautés urbaines marginalisées et sous-représentées et le soutien des échanges transdisciplinaires entre la recherche et la pratique.

Zusammenfassung. Bürgerwissenschaften in urbaner Forstwirtschaft haben die Bedeutung oder Aufgabe, die Öffentlichkeit in die Studien, das Management und die Pflege von urbanen Bäumen zu engagieren und schließen verschiedene Ansätze mit unterschiedlichen disziplinären Grundlagen ein. Zum Beispiel hatten die Bürgerwissenschaften an Prominenz in der urbanen Forstwirtschaft gewonnen, durch Behörden und gemeinnützige Organisationen, die Freiwillige engagieren, um Daten für Kataster sammeln und Überwachungen durchzuführen. Die Anwohner können auch in andere Stadien der urbanen Forstwirtschafts-Forschung und Management involviert werden, einschließlich Rahmenziele und Fragen bezüglich Analysen, Interpretation von Daten und Anwendung von Ergebnissen. Diverse Formen von öffentlichem Engagement haben ausgedehnte Interessensgruppen an die Schnittstelle von Wissensproduktion und Verwaltung von urbanen Grünflächen gebracht, einschließlich Ko-Management und Bürger-ÖkologiePraktiken. Da Behörden, Bundesländer, gemeinnützige Gruppen und Wissenschaftler diese verschiedenen Formen der Bürgerwissenschaften verwenden, gibt es ein Bedürfnis für eine Basisforschung über die Natur der Bürgerwissenschaften in der urbanen Forstwirtschaft, empirische Daten über die beste Praxis verschiedener Herangehensweisen und den Einfluss der Freiwilligkeit auf die Teilnehmer selbst. Diese spezielle Ausgabe von Arboriculture \& Urban Forestry zielt darauf ab, die Stipendien der Bürgerwissenschaften in urbaner Forstwirtschaft durch unter anderem die Themensetzung und dazu beitragende Artikel voranzubringen. In dieser Einführung für diese spezielle Ausgabe schauen wir kurz über Begriffe, die mit Bürgerwissenschaften verbunden sind, und verbinden diese zusammenhängenden Untersuchungsthemenkreise mit urbaner Forstwirtschaft und präsentieren die den Stand der Forschungen sowie der praktischen Bemerkungen, die in dieser speziellen Ausgabe enthalten sind. Wir schließen dann mit einer
Diskussion über die Anforderungen künftiger Forschungsziele der Bürgerwissenschaft in der urbanen Forstwirtschaft, einschließlich technischer Werkzeuge, welche die Demokratisierung von Daten, die Integration von an den Rand gebrachten und unterrepräsentierten urbanen Kommunen sowie der Unterstützung eines interdisziplinären Austauschs zwischen Forschung und Praxis zulassen.

Resumen. La ciencia cívica en la dasonomía urbana es un medio para involucrar al público en el estudio, la gestión y el cuidado de los árboles urbanos e incluye enfoques variados con diferentes bases disciplinarias. Por ejemplo, la participación ciudadana ha ganado prominencia en la dasonomía urbana, con municipalidades y organizaciones sin fines de lucro involucrando a voluntarios en la recopilación de datos para inventarios y monitoreo. Los residentes también pueden involucrarse en otras etapas de la investigación y gestión de bosques urbanos, que incluyen enmarcar objetivos y preguntas, realizar análisis, interpretar datos y aplicar resultados. Diversas formas de participación ciudadana han llevado a las partes interesadas ampliadas al ámbito de la producción de conocimiento y la administración de los espacios verdes urbanos, incluidas las prácticas de cogestión y ecología cívica. A medida que los municipios, estados, organizaciones sin fines de lucro y científicos emprenden estas diversas formas de ciencia cívica, es necesario realizar una investigación básica sobre la naturaleza del compromiso cívico en la dasonomía urbana, evidencia empírica sobre las mejores prácticas para diferentes enfoques y los impactos del voluntariado en su propia participación. Este número especial de Arboriculture \& Urban Forestry tiene como objetivo avanzar en la erudición de la ciencia cívica en la dasonomía urbana abordando esos temas, entre otros, con artículos aportados. En esta introducción al número especial, revisamos brevemente los términos relacionados con la ciencia cívica para conectar estos cuerpos de investigación interrelacionados con la dasonomía urbana, y presentamos los estudios de investigación y las notas de los profesionales incluidos en este número especial. Concluimos con una discusión sobre las futuras necesidades de investigación para la ciencia cívica en la dasonomía urbana, que incluye herramientas tecnológicas para permitir la democratización de datos, la participación de comunidades urbanas marginadas y sub representadas, y el apoyo a intercambios transdisciplinarios entre investigación y práctica. 